\title{
Cévní mozková príhoda při disekci pravé vnitřní karotidy
}

MUDr. Irena Doležalová, Ph.D.', MUDr. Marta Pažourková2, MUDr. Viktor Weiss', prof. MUDr. Milan Brázdil, Ph.D., 3 'I. neurologická klinika, FN u sv. Anny v Brně a LF MU, Brno ${ }^{2}$ Klinika zobrazovacích metod, FN u sv. Anny v Brně a LF MU, Brno ${ }^{3}$ Středoevropský technologický institut, CEITEC MU, Brno

Obr. 1. CT angiografie karotid, transverzální řez-redukcelumen pravévnitřní karotidy za odstupem podmíněná intramurálním hematomem při disekci

Obr. 2. CT angiografie, sagitální rekonstrukce MIP-typickýobrazuzávěru pravé
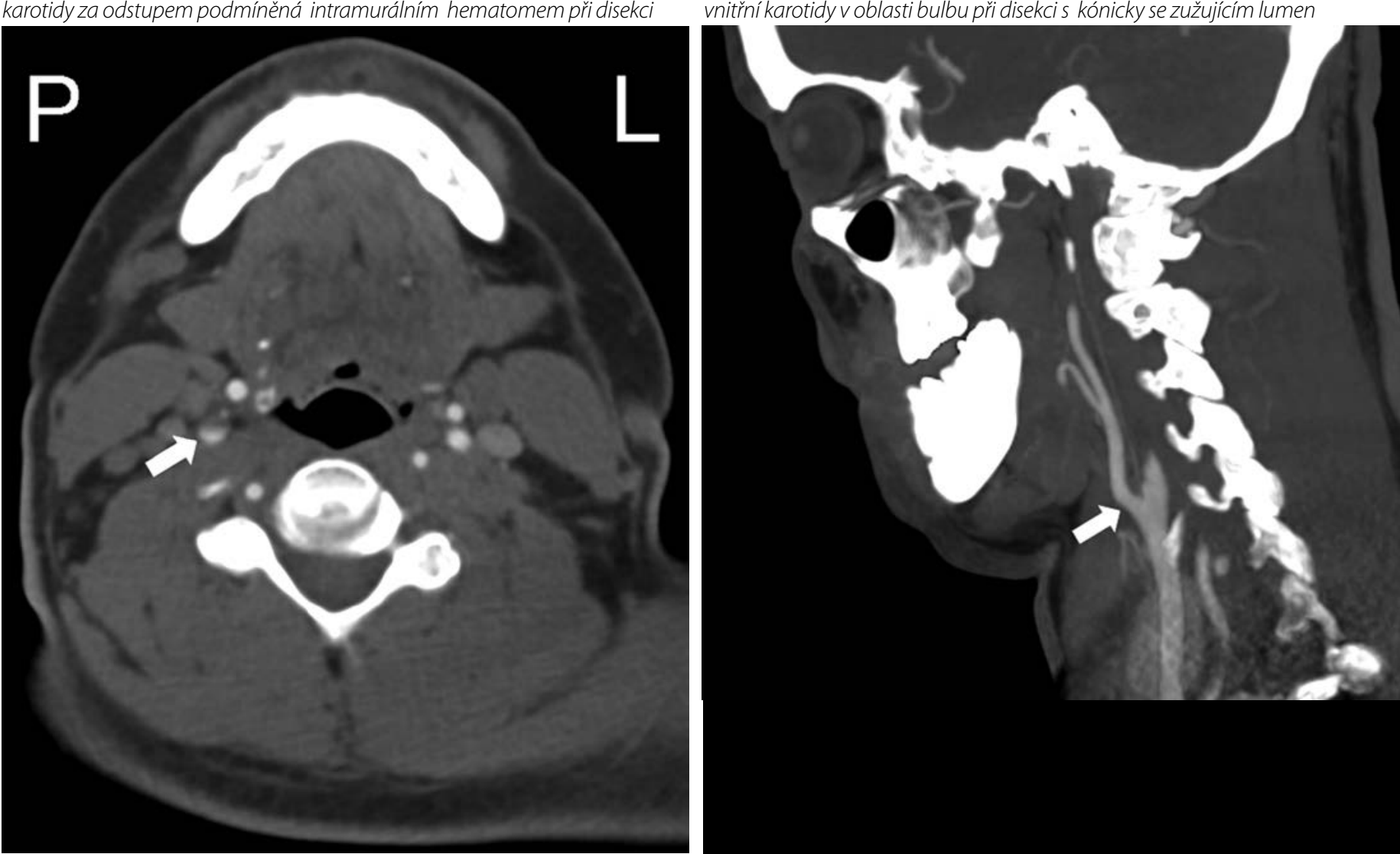

Neurozobrazovací kazuistika ilustruje prípad mladého pacienta (věk 35 let), který byl na naši kliniku přeložen v rámci cévního programu ze spádového iktového centra pro cévní mozkovou príhodu. Pacient byl v zaměstnání, zde v 17:10 došlo k náhlému rozvoji neurologické symptomatologie, klinicky prítomna deviace hlavy a očních bulbů doprava, plegie levé horní končetiny, těžká paréza levé dolní končetiny.
Pacient byl prevezen do spádového iktového centra, zde provedeno CT mozku, včetně CT angiografie, na akutním CT bez čerstvých ischemických změn, na CT angiografii prítomen obraz typické disekce a. carotis interna vpravo (obrázky 1 a 2). Ve spádovém iktovém centru byla provedena intravenózní trombolýza, která byla bez efektu. Pacient byl následně letecky transportován na naše pracoviště k intervenč- nímu výkonu. Digitální subtrakční angiografie potvrdila obraz disekce (obrázek 3). Byl implantován stent, následně provedena dilatace pravé vnitřní karotidy (obrázek 4). Výkon byl ukončen ve 22:05, u pacienta došlo k významné regresi neurologického nálezu, při propuštění z našeho pracoviště byla prítomna lehká paréza levé horní končetiny, na akru byla akcentovaná do těžkého stupně. 
NEUROZOBRAZOVACÍ KAZUISTIKA I

CÉVNÍ MOZKOVÁ PŘíHODA PŘI DISEKCI PRAVÉ VNITŘNII KAROTIDY

Obr. 3. DSA, bočná projekce - obraz disekce pravé vnitřní karotidy s jejím uzá- Obr. 4. DSA, předozadní projekce - zprůchodnění pravé vnitřní karotidy po věrem pred intravaskulární intervencí implantaci karotického stentu (šipka) a jeho dodilatování
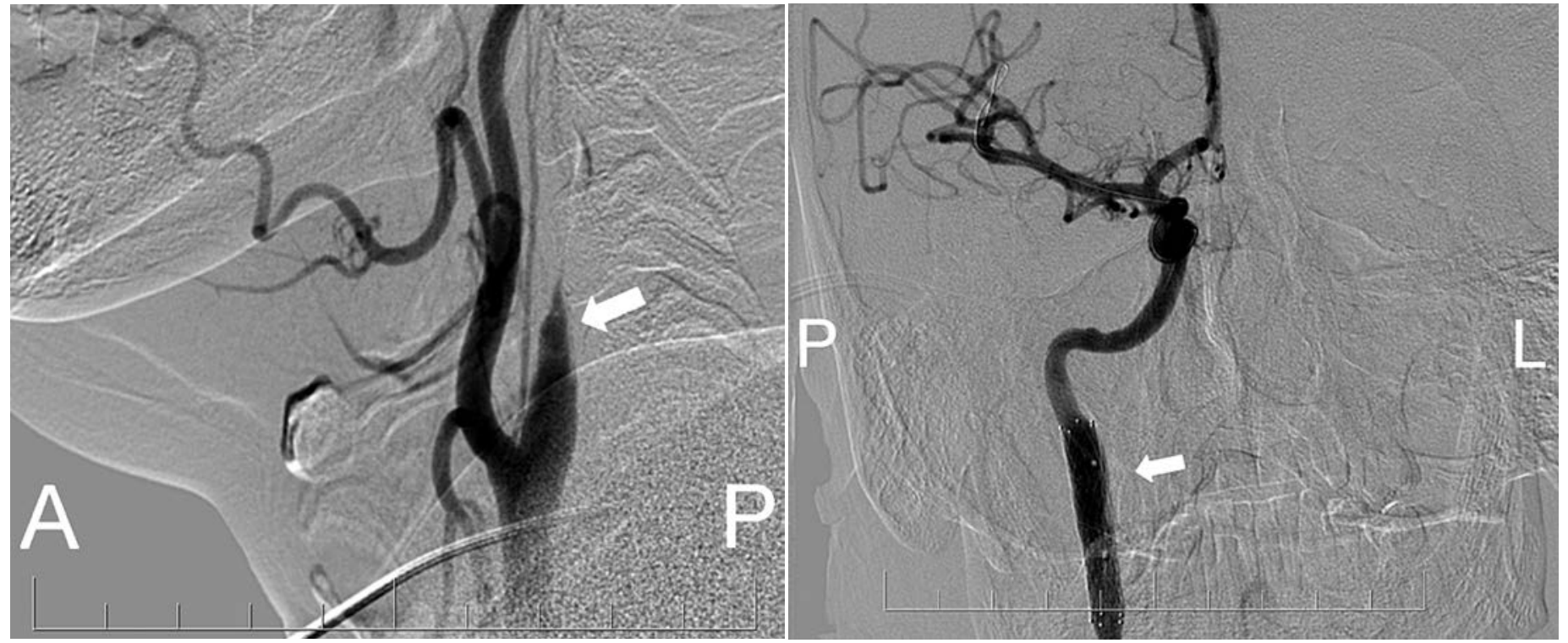